\title{
Erratum to: Determination of Land Use Stress on Drinking Water Quality in Tiruchirappalli, India Using Derived Indices
}

Rajendran Vidyalakshmi • Balan Brindha • Panneer Selvam Benedict Roosvelt • Sundaram Rajakumar • Marimuthu Prashanthi Devi

Published online: 21 February 2013

(C) Springer Science+Business Media Dordrecht 2013

\section{Erratum to: Water Qual Expo Health}

DOI 10.1007/s12403-012-0083-x

In the original article the author group is displayed as: Rajendran Vidyalakshmi, Balan Brindha, Panneer Selvam Benedict Roosvelt, Sundharam Rajakumar, Marimuthu
Prashanthi Devi. The name of one of the authors was not spelled correctly. The correct spelling is Sundaram Rajakumar. Also the affiliation of Marimuthu Prashanthi Devi has to be changed. She is at the Department of Environmental Management. Everything else in the paper remains correct.

The online version of the original article can be found under doi:10.1007/s12403-012-0083-x.

R. Vidyalakshmi $(\bowtie) \cdot$ B. Brindha · P.S. Benedict Roosvelt . M. Prashanthi Devi

Department of Environmental Management, Bharathidasan

University, Tiruchirappalli 620024, Tamil Nadu, India

e-mail: vidyalakshmi07@gmail.com

M. Prashanthi Devi

e-mail: prashanthidevi@gmail.com

S. Rajakumar

Department of Marine Biotechnology, Bharathidasan University,

Tiruchirappalli 620024, Tamil Nadu, India

e-mail: kodairaj@gmail.com 